\title{
Sexual Assault on the College Campus: A Partial Test of Male Peer Support Theory
}

\author{
Falak Ojjeh
}

Follow this and additional works at: https://researchrepository.wvu.edu/etd

\section{Recommended Citation}

Ojjeh, Falak, "Sexual Assault on the College Campus: A Partial Test of Male Peer Support Theory" (2015). Graduate Theses, Dissertations, and Problem Reports. 6342.

https://researchrepository.wvu.edu/etd/6342

This Thesis is protected by copyright and/or related rights. It has been brought to you by the The Research Repository @ WVU with permission from the rights-holder(s). You are free to use this Thesis in any way that is permitted by the copyright and related rights legislation that applies to your use. For other uses you must obtain permission from the rights-holder(s) directly, unless additional rights are indicated by a Creative Commons license in the record and/ or on the work itself. This Thesis has been accepted for inclusion in WVU Graduate Theses, Dissertations, and Problem Reports collection by an authorized administrator of The Research Repository @ WVU. For more information, please contact researchrepository@mail.wvu.edu. 
Sexual Assault on the College Campus: A Partial Test of Male Peer Support Theory

\author{
Falak Ojjeh
}

Thesis submitted to the College of Arts and Sciences

at West Virginia University

in partial fulfillment of the requirements

for the degree of

\author{
Master of Arts \\ in \\ Sociology
}
Walter DeKeseredy, PhD., Chair
Rachel Stein, $\mathrm{PhD}$.
Lisa Dilks, $\mathrm{PhD}$.
Candace Griffith, $\mathrm{PhD}$.

Department of Sociology

Morgantown, WV

2015

Keywords: sexual assault, college campuses, male peer support, fraternities Copyright 2015 Falak Ojjeh 


\section{Abstract \\ Sexual Assault on the College Campus: A Partial Test of Male Peer Support Theory}

Falak Ojjeh

Researchers have identified a number of variables that influence sexual assault on college campuses; peer influence being one of them. According to the sexual assault literature, more than a quarter of victims of sexual assault report their offender was a fraternity member. Additionally, the literature shows that in many sexual assault cases, both the victim and the offender were intoxicated. In applying Walter DeKeseredy's theory of Male Peer Support - allmale groups that legitimate women abuse - to on-campus fraternity organizations, this study examines the link is between the drinking and rape cultures promoted by fraternities, specifically, the use of excessive alcohol by fraternity members and the likelihood of sexual assault. The data from this study are obtained from a 2005-2006 survey Prevalence, Context, and Reporting of Drug-Facilitated Sexual Assault on Campus of Two Large Public Universities in the United States. Analysis of descriptive statistics shows that fraternity members are more likely to sexually assault than non-fraternity members. The results of this study fill the gaps and extend the knowledge of sexual assault committed by fraternity members. The findings of this current study will aid sexual assault researchers in future research. The results of this study will be useful to universities, students and communities across the nation. 


\section{Table of Contents}

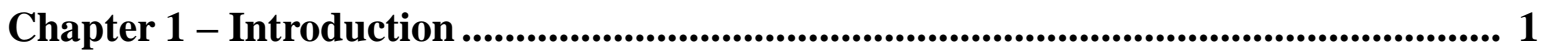

Chapter 2 - Theoretical Framework ...................................................................... 3

2.1 Fraternities and Sexual Assault .................................................... 3

2.2 Male Peer Support Theory ................................................................. 5

2.3 Fraternities as Male Peer Social Support...................................................... 10

Chapter 3 - Research Objectives.............................................................................. 16

Chapter 4 - Data and Methods...................................................................... 18

Chapter 5 - Variables ........................................................................................................... 18

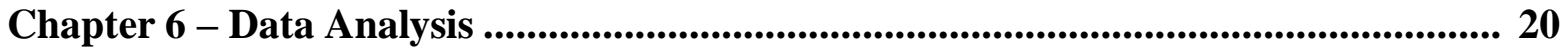

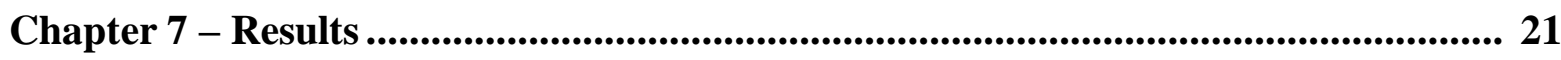

$7.1 \quad$ Descriptive Statistics................................................................. 21

7.2 Chi-Square Analysis................................................................................ 21

Chapter 8 - Discussion .................................................................................... 25

8.1 Limitations and Policy Implications .......................................................... 32

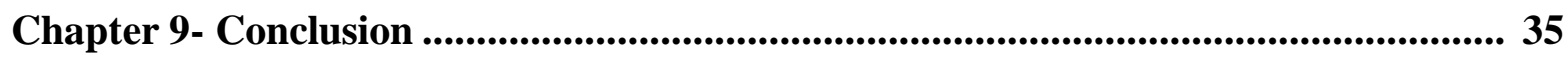

References Cited................................................................................................ 36 
The first fraternity, Phi Beta Kappa, was formed in 1776 on the premises of brotherhood and teaching aspects of professionalism otherwise not taught in school (SJSU, 2014). Over time, these practices have swayed off track, mutating into an organization promoting binge drinking and objectifying women (Weiss, 2013). The binge drinking aspects of the modern day fraternity have been in the news for quite some time. On many college campuses across the United States, partying has become a hobby. Partying is often thought of not only as an excuse to binge drink, but as a large component to the college experience (Weiss, 2013). Fraternities often throw house parties, providing students with alcohol. To many students, these types of parties are ideal, for they provide student who are not of legal drinking age a location to drink. Unlike bars, there is seldom any form of formal enforcement, like a bouncer, at a fraternity party to stop students from binge drinking (Weiss, 2013). Many fraternity parties are themed with provocative undertones and gendered themes, e.g. "Pimps and Ho’s", "Lawyer Bros and Surfer Hoes", "GI Joes and Army Hoes", etc. (Clapp et al. 2008). Due to the nature of these parties, women are overly sexualized and often victimized.

It was not until recent years that fraternities have come under fire for the ways they objectify women. Consider these examples: Yale University’s Delta Kappa Epsilon chapter chanted, 'No means Yes, Yes means Anal! My name is Jack, I'm a necrophiliac; I fuck dead women, and fill them with my semen!" outside the women's dormitory on the night of October 13, 2010 (Beyerstein, 2010). At Texas Tech in 2004, these same words were displayed on a banner next to a display of a working sprinkler with a woman's genitals attached to it, at a Phi Delta Theta hurricane party (Kingkade, 2014). In 2013 a brother of the Phi Kappa Tau chapter at Georgia Tech emailed his fraternity brothers with a "how to" guide on "luring rape bait," 
including instructions on how to talk to girls, how to get them drunk, how to gropingly dance with them, and how to coerce them into having sex (Kingkade, 2013). More recently in 2014, the members of the Tau Kappa Epsilon chapter at the University of Wisconsin-Milwaukee were under investigation for a color-coded date rape system (Herzog, 2014). These fraternities, through their chants, emails, party practices, and more, encourage rape. Rape supportive messages are not new, but continue to warrant social, scientific, and political attention.

Sexual assault ${ }^{1}$ on the college campus remains a major social problem. It is estimated that one in five undergraduate women will report experiencing some variant of this harm (Krebs et al. 2007). Krebs et al. (2007) found that the majority of sexual assaults occurred while the woman was incapacitated from either drug or alcohol use. Mohler-Kuo, et al. (2004) found that in as many as three in four sexual assaults on college campuses, the victims reported being too intoxicated to consent at the time of the incident. Kilpatrick et al. (2007) found that sexual assault was more likely to occur if the victim was voluntarily drinking alcohol prior to the incident. This finding is not surprising considering the party culture on many college campuses, in which hooking up, binge drinking, and using illicit drugs have become the norm (Weiss, 2013).

Fraternities are often found at the hub of the college party culture, hosting parties and providing underage students a place to drink (Krebs et al. 2007; Weiss, 2013). Consequently, fraternities contribute to the number of rapes committed on campus. Foubert et al. (2007) found that fraternity men were three times more likely to commit sexual assault than non-fraternity men. With this study, I aim to answer: What is the link is between the drinking and rape cultures

\footnotetext{
${ }^{1}$ Sexual assault is classified into four types: Sexual contact, sexual coercion, attempted rape and completed rape. Unwanted sexual contact includes: fondling, kissing, misuse of authority and threats of harm. Sexual coercion involves threats of bodily harm or any means of verbal pressure. Attempted and completed rape involves the attempted or completion of unwanted sexual intercourse (Koss et al. 1987).
} 
promoted by fraternities? Specifically, does the use of excessive alcohol by fraternity members increase the likelihood of sexual assault?

To examine the relationships between fraternity drinking and rape cultures and their potential impact on rates of sexual assaults by fraternity members, this research utilizes Male Peer Support Theory (DeKeseredy and Schwartz, 2013). Male peer support theory examines men's "attachments to male peers and as the resources that these men provide which encourage and legitimate woman abuse" (DeKeseredy and Schwartz, 2013: xiv). This theory argues that when men experience anxieties in their dating relationships which challenge their dominance, they may turn to their male peers for advice and numerous forms of social support. The behaviors and ideologies of certain all-male groups often promote and sanction woman-abusing attitudes which in turn may pressure men to victimize women (DeKeseredy and Schwartz, 2013).

This theory has been applied to campuses, and has shown evidence to explain how male peer support leads to sexual assaults. Although this theory has been tested on college campuses, there is a missing link. Because most of the tests of this theory have taken place in Canada and because on-campus fraternities do not exist in Canada, tests of the model lack data on this important all-male group. The main objective of this research is to address this limitation by testing the theory using a United States-based college data set which includes information on sexual assault and fraternity membership.

\section{THEORETICAL FRAMEWORK}

\section{Fraternities and Sexual Assault}

According to Krebs et al. (2007) more than a quarter of college sexual assault victims report that their assailant was a fraternity member. Additionally, Foubert et al. (2007) found that in their first year of college, 8 percent of fraternity members commit sexual assault, in 
comparison to 2.5 percent of non-fraternity members. Furthermore, it has been found that fraternity members are more inclined to report using drugs or alcohol to obtain sexual intercourse, and that their peers generally do not protest if drugs and alcohol are used on a woman to obtain sexual intercourse (Abbey, 2002). Fraternity members are also more inclined to report that their peers would condone sexual aggressive behaviors (Boeringer et al., 1991; Menning 2009).

However, some studies have found no significant difference in regards to crimes that occur at fraternity parties, including sexual assault, as compared to other house parties (Harford et al., 2003; Weiss, 2013). In both studies, alcohol was found to increase aggression and lower self-control for both men and women. Regardless of location, the consumption of alcohol led to the perpetration of illicit behavior and using "I was drunk" as an excuse (Weiss, 2013). The drinking setting (e.g. bars or off-campus house parties) often encompasses several dimensions either posing risk (e.g. illicit drugs and binge drinking) or protection (e.g. being with friends) (Clapp et al., 2000; Harford et al., 2003).

Despite these contradictory findings, Foubert et al. (2007) found that fraternity members were three times more likely to engage in sexual assault than non-fraternity members. They found that it was the "fraternity experience" that led them to commit sexual assault. Within this "fraternity experience" a culture of group norms that emphasizes male sexual dominance over women is created (Foubert et al. 2007). Arguably, this "fraternity experience" mimics the key causal factors of the modified male peer support model (DeKeseredy and Schwartz, 2013). This model argues that membership in all-male social groups fosters the conditions that lead to woman abuse. Specifically, the "fraternity experience" includes group secrecy, the absence of deterrence, a narrow conception of masculinity, the heavy use of alcohol and the sexual 
objectification of women, all of which may lead fraternity members to commit sexual assault. By understanding this "fraternity experience" this research aims to further the literature in explaining the connection between fraternity membership and alcohol consumption and how it leads to sexual abuse.

\section{Male Peer Support Theory}

Male peer support theory focuses on male peer group behaviors, attitudes, and ideologies that promote and justify woman-abuse (DeKeseredy and Schwartz, 2013). DeKeseredy originally constructed this theory in $1988^{2}$, explaining how all-male peer groups encourage sexual assault within dating relationships. He maintained that many men all-male peer groups promote and legitimize sexual assault (DeKeseredy and Schwartz, 2013). DeKeseredy (2008) found that sexually abusive men generally learned their behavior socially learned through interactions with other male peers.

Although DeKeseredy's original model explained how male peer groups motivate sexual assault in dating relationships, he and Schwartz (1993) added important factors that were not included in the original model. These additions to the theory now allow for broader explanations about how all-male group ideologies contribute to sexual assault in general, not just dating relationships. As illustrated in Figure 1, the original model is encompassed in the first part of the model - Courtship Patriarchy, Dating Relationships, Stress, Male Peer Social Support. The revised model includes the addition of Membership in Social Groups, Heavy Use of Alcohol, Narrow Conception of Masculinity, Group Secrecy, Sexual Objectification of Women, and Absence of Deterrence. These additions can be used to link membership in social groups to woman abuse.

\footnotetext{
2 See Schwartz and DeKeseredy (1997) and DeKeseredy and Schwartz (2013) for a more in-depth look at the history of male peer support theory.
} 


\section{Membership in Social Groups}

The support system necessary to create a group can be found in any geographical location. These support systems are formed and strengthened when likeminded individuals come together. It is often argued that when men group themselves with one another, they create a bond that separates them from the "others," which is women. Through this "othering" process, the women are seen as being of lesser worth and as objects. It is often a common belief among all-male groups that women are here to be exploited and to act as males' sexual conquests (Schwartz and DeKeseredy, 1997). These beliefs, coupled with specific group behavior, often support and lead to woman abuse.

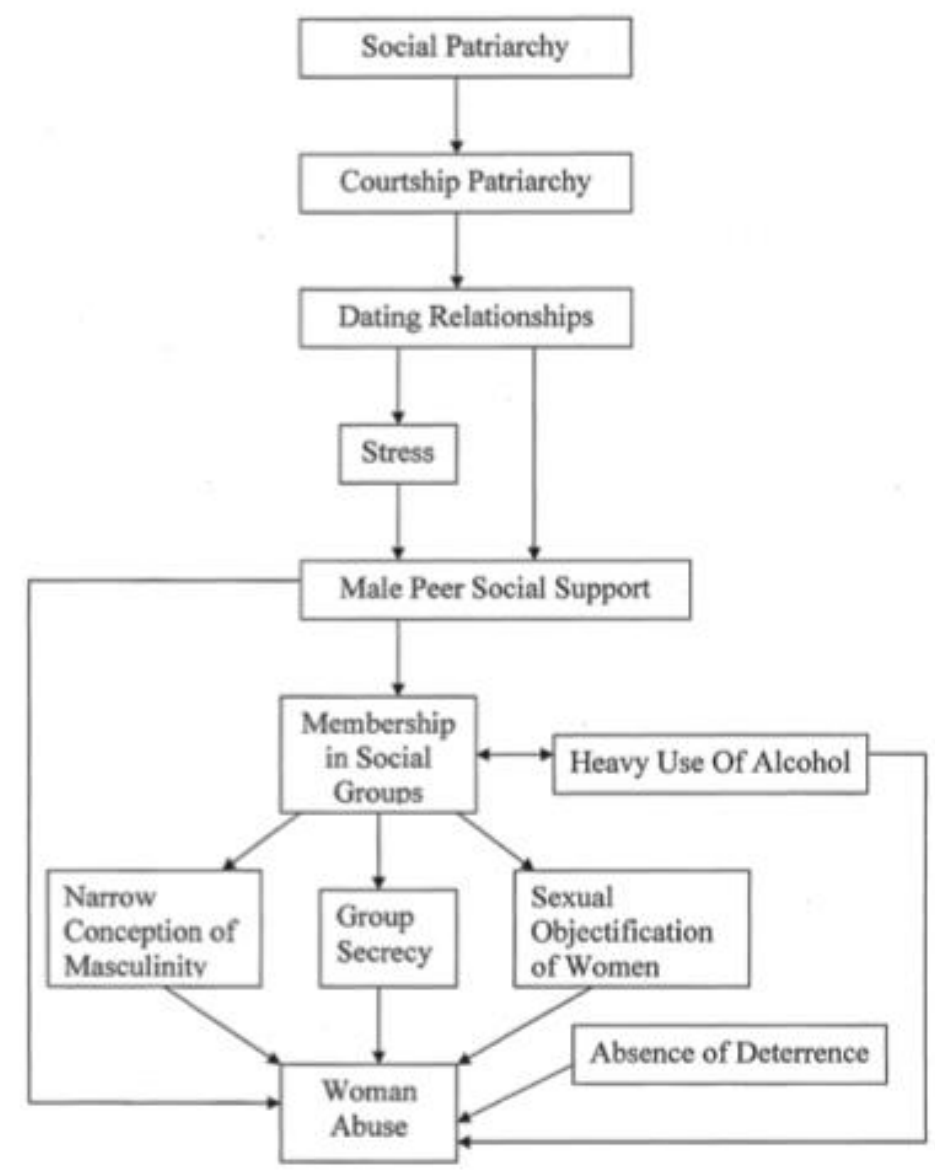

Figure 1. Schwartz and DeKeseredy's (1997, p. 46) Male Peer Support Model 


\section{Narrow Conception of Masculinity}

Overall, scholars often assert that heterosexuality is constructed around the dominant form of masculinity (hegemonic masculinity) and the ability to claim power and prestige over others (Connell, 1987; Dean, 2013; Kimmel, 2005; Pascoe, 2007). Hegemonic masculinity includes the following: (1) avoiding all things feminine, (2) limited expression of emotions, (3) showcasing aggressions, (4) exhibiting independence, (5) striving for a higher status, (6) disconnected attitudes towards sexuality, and (7) homophobia (Levant 1994). With this definition of manhood comes a competition of sexual conquest.

Donaldson (1993) suggests that in accordance with hegemonic masculinity, being the "macho," "women exist as potential sexual objects for men while men are negated as sexual objects for men. Women provide heterosexual men with sexual validation, and men compete with each other for this form of validation (645). As Sanday (2007) points out, this hyper-sexual way of proving one's masculinity is a competition to "get laid". This can include such things as "breaking down the barrier" and "working a yes out" by any means possible. Sexual dominance and validation includes the number of women a man has sexual intercourse with, whether that is consenting sexual intercourse or not (Murnen and Kohlman, 2007).

\section{Sexual Objectification of Women}

Women are often demeaned and objectified because of this very narrow conception of masculinity. Objectification is defined as the treatment of a person as an object (Papadaki 2010). When a woman is objectified, she is defined and perceived as being insignificant. As Schur (1988) points out,

"[The] social subordination and sexual objectification of women are central to much of the depersonalized, commercialized, and coercive sexuality found in modern American 
society. At the present time, it is primarily female sexuality that is objectified, commoditized, and coercively violated" (12-13).

Miller and Schwartz (1992) identify many objects used to objectify women in all-male groups, particularly their drinking rituals such as ice trays that make ice cubes in the shape of naked women or in the shape of a breast, drink stirrers in the shape of a naked woman, and drink ware plastered with imagery of naked women. As these artifacts and as Schur denotes, the female anatomy is often overly sexualized. These items that objectify a woman's body are, more often than not, meant to be humorous. As DeKeseredy and Schwartz (1997) point out, humor in this manner helps in the desensitization of sexual assault.

It has also been found that men in organized social groups are more inclined to watch pornography together (Foubert et al. 2011; Sanday, 2010). Furthermore, there is a growing theme in pornography that leads to rape-supportive ideologies. Researchers evaluating the most popular pornography found that $88 \%$ of the scenes included some form of physical aggression towards women, for example spanking, open-handed slapping, hair pulling, choking and bondage (Bridges et at., 2010; Foubert et al., 2011). The average ages of men watching pornography are between the ages of 18 and 25 (Boies, 2005; Buzzell, 2005; Carrol et al., 2008; Foubert et al., 2011). It has been found that, on average, $76 \%$ to $87 \%$ of college aged men view pornography annually, and approximately $48 \%$ of men view it weekly (Boies, 2002; Carroll et al., 2008; Foubert et al., 2011). Men in all-male groups are also more inclined to use degrading language to describe a woman's body (Murnen, 2000). Taken together, these behaviors strengthen attitudes towards male domination and the objectification of women (Bleecker and Murnen, 2005), and according to male peer support theory, contribute to woman-abuseing ideologies, attitudes, and behaviors. 


\section{Group Secrecy}

Schwartz and DeKeseredy (1997) describe group secrecy as the bond that keeps men from exposing the deviant behavior of their peers. DeKeseredy and Schwartz (2013) state that "silence is one of the more effective ways that all-male groups legitimate and perpetuate sexual assault" (65). This silence acts as a form of protection, telling these wrongdoers their actions are endorsed.

Absence of Deterrence

DeKeseredy and Schwartz (2013) also found that more often than not, sexual assault cases go unreported because of peer pressures from the community not to report, or out of fear of public persecution. In determining that societies that normalize sexual assault, Schwartz and Leggett (1999) state:

"If too many men act like they can force sexual intercourse on a woman any time they wish on college campuses and get away with it, it is because it is too often true. In fact, they can often act with impunity... When approximately five percent of victimized women are reporting even forcible rape, there is very little reason for a rapist to fear any consequences of his action (p. 266-267)."

Oftentimes, many of the women that are sexually assaulted blame themselves for the assault. Reasons for this self-blame include: the clothing the women wore, intoxication levels, and being at the wrong place at the wrong time.

Heavy Use of Alcohol

Alcohol consumption is considered to be a hallmark of masculinity, and is often the most visible behavior associated with all-male groups. It is seen as a communicative lubricant, aiding in social interaction and "[letting] your guard down" (Desantis, 2007; 167). When heavy alcohol 
consumption is combined with the practices of hegemonic masculinity, the risk of sexual assault is increased (Desantis, 2007; Boswell and Spade, 1996; Martin and Hummer, 1989; O'Sullivan, 1991; Sanday, 2007). Studies indicate that men feel more powerful when drinking, and as a result are more likely to be sexually aggressive (Abbey, 2002; Brown et al., 1980; George and Norris, 1991; Presley et al., 1997).

Many men with the intention of sexual assaulting a woman also aim to intoxicate their female acquaintances to restrict their ability to resist (Abbey, 2002). The more a woman drinks, the more at risk she is to be the victim of sexual assault, simply because she is unable to fight off her attacker. On average, at least 50 percent of college students' sexual assaults involve alcohol (Abbey, 2002; Abbey et al., 1996, 1998; Copenhaver and Grauerholz, 1991; Harrington and Leitenberg, 1994; Presley et al., 1997). Harrington and Leitenberg (1994) found that 55 percent of the sexual assaults reported by college women involved alcohol consumption, and in 97 percent of the alcohol-related sexual assaults, both the victim and the perpetrator had consumed alcohol.

\section{Fraternities as Male Peer Social Support}

With the establishment of the first fraternity, these all-male groups have been thought of as systems of camaraderie and brotherhood, promoting and supporting masculinity within their members. From the start, fraternity brothers defined their identity through the segregation of others. Syrett (2009: 3) notes, "In search of respect and prestige, men have performed particular acts, behaved in particular ways, and made particular decisions. In so doing, men in fraternities have structured not only their own lives, but also the lives of many of their fellow students." These established structures directly correlate to the modified male peer support model, as illustrated in Figure 1. 


\section{Membership in Social Groups}

From the very beginning, fraternities have had a reputation of being "the big men on campus." Bogle (2008) found that fraternity membership is an esteemed attribute to young men. There is a process to become a fraternity member, and it is structured like a competition. The first step is rushing, which means the fraternity has chosen an individual to be a potential member. The second step is pledging, which involves sole commitment to that fraternity. The pledging process entails a series of punishments from the active fraternity members to the potential members in exchange for the honor of membership (Syrett, 2009). The pledging process is comparable to military training. "What we do really is show them that they have to rely on each other, trust each other, no matter what...Yeah it's tough, but it has to be. When they come out the other end, they are brothers" (Desantis, 2007: 173). Traditionally, it has been found that the pledging process guarantees that the most masculine men become brothers. Men who are less athletic, less likely to drink, and less inclined to have aggressive attitudes towards sex are more likely to drop out during the pledging process or never attempt to pledge in the first place (Martin and Hummer, 1989; Bogle, 2008). Membership in these particular social groups is tied to a heavy use of alcohol, a narrow conception of masculinity, group secrecy, sexual objectification of women, and the absence of deterrence leading to woman abuse.

\section{Narrow Conception of Masculinity}

Fraternity membership influences a narrow conception of masculinity. Schwartz and DeKeseredy (1997) note that how, within fraternities, it is often demonstrated that men are supposed to be wealthy, athletic, sexually domineering, have sex with lots of women, and have a high tolerance for alcohol. Through the promotion of hegemonic masculinity, fraternity members believe that women are present only to satisfy their sexual urges. In regards to 
promiscuity and misogyny, DeSantis (2007) found that "the ideal masculinity is hypersexual, promiscuous, and heterosexual," which is evident when an interviewed fraternity member shares how he and another member have "a competition of who's fucked the most girls this year" (4445). Fraternity members also engage in competitive conversation about the number of women they have had sexual relations with and the different means they achieved it. These conversations "channel sexual expression and communicate expected sexual behavior. In telling one another what to expect, how to interpret sexual signals, and how to act at parties, the brothers encourage one another in what can only be described as rape-prone behavior" (Sanday, 2007; 131).

Researchers who study fraternity parties argue that their large parties tend to be patriarchal in nature, with men hosting, enforcing the "rules" and setting the pace of inebriation (Armstrong et al. 2006, 2013; Harford et al., 2003; Kimmel, 2008). Women who venture into these "masculinized" parties may become fair game for unwanted sexual advances by overly inebriated, and highly masculinized men. Syrett (2009) points out, "[that] as masculinity became increasingly defined through active heterosexuality during the twentieth century, many fraternity men used women, often against their will, to bolster their masculinity" (p. 3).

\section{Sexual Objectification of Women}

As many fraternity members live with other members, they surround themselves with artifacts that objectify women. Many walls are plastered in posters of scantily dressed women in objectifying positions. But objectifying items do not stop at the walls; they are found in kitchens and anywhere that rituals maintaining relationships with one another may occur. Some of these items include: drink ware, pornographic imagery on cellphones and laptops, and objectifying language and images plastered on clothing. In recent years, fraternity members have turned to 
social media sites to continually exploit and objectify women. Just this year, the Kappa Delta Rho fraternity at Penn State was found to have posted and archived nude or partially nude photographs of unconscious women from parties on private Facebook pages (DeJesus, 2015). Many of these photographs were digitally commented on by alumni and current members with misogynistic jokes and messages.

Kimmel (2008) explains how the media plays an active role in how fraternity members view sex. In this day and age, the use of media as a form of entertainment is at an all time high. Fraternity members often play video games together, as well as watch and share pornography together. The dominant emotion in all of these forms of media is violence (Kimmel, 2008). In several video games, women are often scantily dressed and are casted as pole dancers and prostitutes. In popular video games, characters can harass, attack, and have sex with them (Beck et al., 2012; Dietz, 1998).

Pornography, like video games, is a way for fraternity members to feel empowered (Kimmel 2008). Due to the substantial amount of pornography fraternity members watch together, they are more inclined to believe that women enjoy physical aggression in sex, that women pretend to not want to have sex in order to be coerced, that women secretly want to be raped, that promiscuous women will have sex with anybody, and that men are in control of relationships (Boeringer, 1999; Foubert et al., 2011). Sanday (2007) notes,

"Given the importance [fraternity members] attach to group cohesion and sexual conquest, and the fact that the intoxication/disorientation/confusion of the woman is explicitly represented in the porn fantasy as female sexual desire, the motivation for exploiting a vulnerable woman after a party is very strong indeed" (141). 
Fraternity parties also tend to be overly-sexualized settings where the goal is to "hook up" with someone for sex. Fraternity membership legitimates the objectification of women, often seeing women as sexual conquests, promoting the different ways to "get laid".

\section{Group Secrecy}

Aiken (1882) explains that, "secrecy may be employed to exert the power of a mystery over the outside world, the societies become "invested with a factitious importance"" (as cited in Syrett, 2009: 33). Aiken expresses the appeal of mystery that fraternities have. Not only does secrecy serve to define difference, it supports loyalty among those who possess the secret. This loyalty lays the foundation for the ability to keep further secrets that may arise around the actions of other members. Fraternal secrecy serves two functions: it both promotes and protects members when they break the rules and laws (Simmel, 1950; Syrett, 2009).

Fraternity membership encourages group secrecy. Kimmel (2008) notes how, "challenging your roommates, stepping in to stop sex from happening when a woman is clearly too drunk to consent or to refuse sex, is a betrayal of brotherhood" (252). This silence often expressed by fraternity members, show their brothers the acceptability of sexual assault. Kimmel (2008) also explains how women and men are seen as being on opposite teams, with fraternity members being the offense. If a fraternity member defends or protects a woman they are seen as switching teams or "committing treason" (252). This culture of silence fueled by peer loyalty discourages the reporting of incidents of sexual assault to authorities.

\section{Absence of Deterrence}

In an ethnographic study, Armstrong and Hamilton (2013) found that many universities harbor a "party pathway," that many students choose to engage in. This pathway exemplifies how the Greek system is seen as a commodity that aids in bringing money in to the university. 
The Greek system provides "affluent, white, and socially oriented students" (p. 15), who organize events and parties that help facilitate the purchase of property on university grounds an exemption of supervision. As a result, fraternity membership has an esteemed status on college campuses, prompting an absence of deterrence. Accordingly, when fraternity members engage in prohibited behaviors, administrators often turn the other cheek. DeKeseredy and Schwartz (2013) note how when it comes to sexually aggressive behavior, many fraternity members find no deterrence at all. Their friends often encourage this behavior. Correspondingly, DeKeseredy and Flack (2007) confirm that many fraternity brothers have amnesty from punishment, even in cases of gang rape. As many universities often turn the other cheek when a fraternity brother rapes a female student, fraternity members have come to believe that it is tolerable to sexually assault.

Heavy Use of Alcohol

Fraternity men often suggest a culture of drunkenness, as famously represented in the movie Animal House (DeSimone, 2007). There is evidence to support the claim that fraternity men binge drink more frequently than non-fraternity men. Cashin, Presley and Meilman (1998) found that students in the Greek system regularly consume more alcohol, and binge drink much more frequently than the other students. Specifically it is estimated that 75 percent of fraternity members compared to 45 percent of non-fraternity members are binge drinkers (Caron et al, 2004; Weschler 1995). Eagly (1978) and Moos (1979) have argued that fraternities typically engage in excessive alcohol consumption to reaffirm their masculine identities. Subsequently, they often discuss the many different ways that they can sexually assault women that they come into contact with. "Drinking with the boys" is a conducive environment for setting up the discourse on how to "work a yes out" (Sanday, 2007: 131). This is representative in the email 
sent by one brothers of the Phi Kappa Tau chapter at Georgia Tech to his other brothers, with a "how to" guide on "luring rape bait." This email contained what he called the "7 E's of HOOKING UP!" which concluded that if all else fails in getting a girl to a room to, "GO GET MORE ALCOHOL” (Kingkade, 2013).

\section{RESEARCH OBJECTIVES}

Although several studies show that Greek membership is associated with increased risk of rape and sexual assault (Armstrong et al., 2006; Armstrong and Hamilton, 2013) some studies have found no significant differences in the occurrence of these crimes at fraternity parties as compared to other house parties (Harford et al., 2003; Weiss, 2013). The purpose of this study is two-fold. First, the contradictory findings with regard to Greek membership and sexual assault warrant further investigation. Second, an application of male peer support theory can not only offer a theoretical framework for examining the relationship between fraternity membership and assault, specifically through the mechanism of heavy drinking, but will also fill the empirical gap in the male peer support literature, which lacks validation in this important all-male group.

\section{Hypotheses}

The modified male peer support model contends that membership in certain all-male social groups encourages and legitimates sexual assault on the college campus through several causal factors. The main focus of this research, however, is only on the influence of the heavy use of alcohol. Partying is often found to be a large component to the college experience (Weiss, 2013). Fraternity parties are often found at the epicenter of the college party culture, providing students with alcohol and a place to drink. Also in accordance with the college party culture, it is estimated that 75 percent of fraternity members compared to 45 percent of non-fraternity 
members are binge drinkers (Caron et al, 2004; Weschler 1995). Figure 2 illustrates the hypotheses tested.

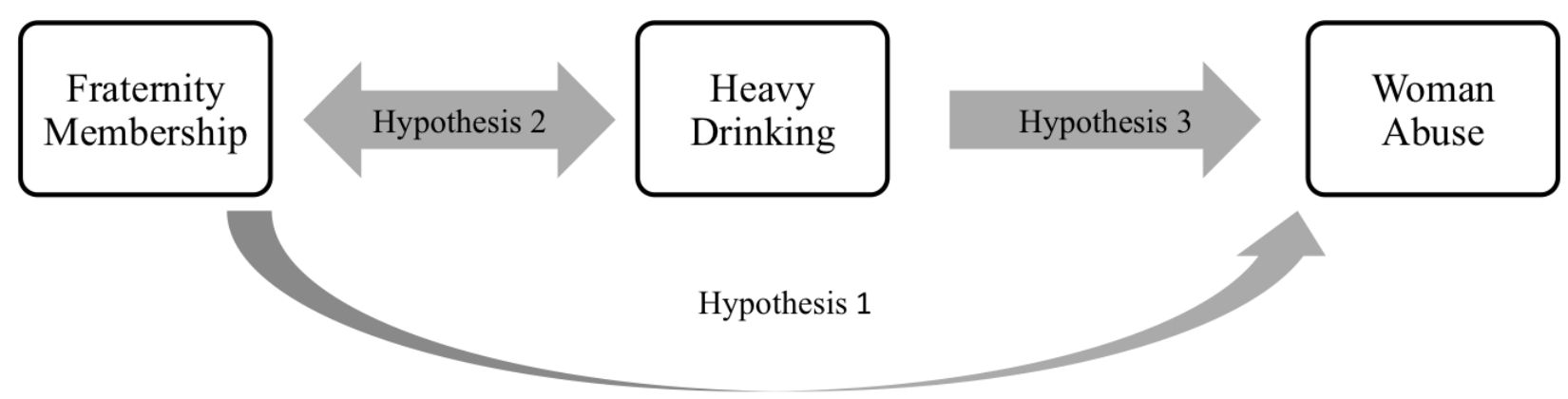

\section{Figure 2: Hypotheses Derived and Tested from Male Peer Support Theory}

Hypothesis 1: Fraternity members are more likely to sexually assault than non-fraternity members.

Hypothesis 2: Fraternity members are more likely to consume alcohol than non-fraternity members.

Hypothesis 3a: Fraternity members are more likely to consume alcohol prior to sexually assaulting incapacitated women than non-fraternity members.

Hypothesis 3b: Fraternity members are more likely to target and sexually assault incapacitated women than non-fraternity members.

The Hypotheses 1-3a test the relationships asserted in male peer support theory. Hypothesis $3 \mathrm{~b}$ is an ancillary hypothesis, not directly predicted by the theory but relevant to sexual assault on college campuses. The addition of Hypothesis $3 \mathrm{~b}$ was to primarily get an understanding of whether being inebriated increased the likelihood of being sexually targeted. As stated previously, sexual assault is more likely to occur of the victim was voluntarily drinking 
alcohol prior to the incident (Kilpatrick et al., 2007). Also, it has been found that the majority of college sexual assaults occur while the woman was passed-out from drug or alcohol use.

\section{DATA AND METHODS}

This study uses data originally collected between 2005 and 2006 from two public universities in the United States, one located in the South and the other located in the Midwest. The survey, "Prevalence, Context, and Reporting of Drug-Facilitated Sexual Assault on Campus of Two Large Public Universities in the United States", made available through the InterUniversity Consortium for Political and Social Science Research (ICPSR), was run by Krebs et al. (2007). The researchers main objective was to understand the prevalence, nature and reporting of sexual assaults on college campuses. They had two service-oriented objectives: 1) to educate students about sexual assault and safety precautions, and 2) to provide information on the campus and community to the students. The study was funded by the United States Department of Justice. The sample was composed of 1,375 undergraduate men out of 11,528 males at both universities, ages ranging from 18 to 25 . Subjects were recruited randomly via email with a link to the web-based survey and a study ID number.

\section{Variables}

Dependent Variable: Sexual Assault

For the purpose of this research, sexual assault is the dependent variable (e.g., Woman Abuse). This binary variable will be operationalized using the following questions from the sexual assault survey. Each of these questions were analyzed separately, as one looked for attempted sexual assault and the other looked at committed sexual assault. The respondents were asked to indicate either yes or no to the following: 
Since you began college, have you attempted but not succeeded in having sexual contact with someone when they were unable to provide consent or stop what was happening because they were passed out, drugged, drunk, incapacitated, or asleep?

Since you began college, have you had sexual contact with someone when they were unable to provide consent or stop what was happening because they were passed out, drugged, drunk, incapacitated, or asleep?

\section{Independent Variables}

For the purpose of this research, the following independent variables will be used to examine the key relationship from male peer support theory on sexual assaults committed on college campuses.

Greek Membership. The first independent variable will be operationalized using the following question from the sexual assault survey to determine Greek membership (e.g., Membership in Social Groups). Each of the respondents were asked to indicate either yes or no:

Since you began college, have you pledged or joined a "Greek" social organization i.e., a fraternity or sorority?

Substance Use. The following questions will be used to examine the use of drugs and alcohol (e.g., Heavy Use of Alcohol). The first variable measures the males' general alcohol consumption. This is measured in two ways, using the following questions from the sexual assault survey. Both questions utilized the following 5-point Likert scale: never, less than once a month, once or twice a month, once or twice a week, and daily or almost daily:

Since you began college, about how often have you consumed alcohol?

Since you began college, about how often have you consumed enough alcohol to get drunk? 
The second variable measures the substance use of the male offender. This is measured in two ways, using the following questions from the sexual assault survey. Each of the respondents were asked to indicate either yes or no:

1. Just prior to the incident/any of the incidents, had you been drinking alcohol?

2. Were you drunk?

The third variable measures the substance use of the victim. For the following question, the respondents were asked to indicate if the offender knew if the victim was: drinking, using drugs, both drinking and using drugs, drinking or using drugs but could not tell which, neither, or didn't know:

Just prior to the incident/any of the incidents, was the person/were any of the people that you had/attempted to have sexual contact with voluntarily drinking alcohol or using drugs?

\section{Data Analysis}

Cross-tabulation analysis was used to measure the relationship between the variables of fraternity association, victim substance use, offender substance use, and attempted and committed sexual assault. Cross tabulations provide a way of comparing and analyzing the relationship of one variable with another variable. Chi-Square tests were run to determine if the relationships between the variables were statistical significant. Fischer's Exact Test was run with the smaller sample sizes. Cramer's V was used in addition to look at the strength of the relationship between the variables. To test each of the hypotheses, I performed the following cross-tabulations:

Hypothesis 1: Attempted Sexual Assault X Greek Membership Completed Sexual Assault X Greek Membership 
Hypothesis 2: Alcohol Consumption X Greek Membership

Drunk Often X Greek Membership

Hypothesis 3a: Offender Drinking X Greek Membership

Offender Drunk X Greek Membership

Hypothesis 3b: Victim Alcohol or Drug Use X Greek Membership

Hypothesis 1 and Hypothesis 2 looks at the entire male sample, whereas both parts of Hypothesis 3 look at only males that report to attempting or committing sexual assault.

\section{RESULTS}

\section{Descriptive Statistics}

Overall, there were 40 self-reported cases of both attempted (16) and completed (24) sexual assault. Of the 1,373 male respondents, 217 reported to be fraternity members (15.80\%).

\section{Chi-Square Analysis}

The results presented in Table 1 show the cross-tabulated self-reports of the attempted and committed sexual assaults of all of the male respondents. Of the 217 fraternity members, 6 admitted to attempted sexual assault, whereas 8 admitted to committing it. Of the 1,156 nonfraternity members, 10 admitted to attempting to commit, while 16 admitted to committing. A chi-square test finds that fraternity members are more inclined to commit or attempt sexual assault, offering support to Hypothesis 1. This table indicates that the association of fraternity members on attempting or committing sexual assault is statistically significant at the 0.05 level in both cases, but in looking at the Cramer's V results, these relationships are only very weakly correlated ( 0.065 for attempted sexual assault and 0.064 for committed sexual assault). 
Table 1: Cross-Tabulations of Fraternity Members Who Admitted to Committing or Attempting Sexual Assault

\begin{tabular}{|c|c|c|c|c|c|}
\hline & \multicolumn{2}{|c|}{ Fraternity Members } & \multicolumn{3}{|c|}{ Non-Fraternity Members } \\
\hline & $\mathrm{N}$ & Percentages & $\mathrm{N}$ & Percentages & \\
\hline $\begin{array}{l}\text { Attempted Sexual Assault on } \\
\text { Incapacitated Victims }\end{array}$ & 6 & $2.8 \%$ & 10 & $0.9 \%$ & \\
\hline Chi Square & & & & & 5.726 \\
\hline Cramer's V & & & & & 0.065 \\
\hline P-Value & & & & & 0.017 \\
\hline $\begin{array}{l}\text { Committed Sexual Assault on } \\
\text { Incapacitated Victims }\end{array}$ & 8 & $3.7 \%$ & 16 & $1.4 \%$ & \\
\hline Chi Square Test & & & & & 5.640 \\
\hline Cramer's V Test & & & & & 0.064 \\
\hline P-Value & & & & & 0.018 \\
\hline
\end{tabular}

Table 2 illustrates that fraternity members consume alcohol more regularly than nonfraternity members offering support to Hypothesis 2 . Specifically, 253 (21.8\%) fraternity members admitted to drinking once or twice a week. This table also indicates that only $8(3.7 \%)$ admitted to never drinking, whereas 128 (59\%) admitted to drinking once or twice a week. Of the 1,156 non-fraternity members, $200(17.3 \%)$ admitted to never drinking. According to the chi-squared test, the relationship between fraternity members and alcohol consumption is statistically significant at the 0.001 level, and the Cramer's V results $(0.238)$ indicate a moderately strong association between the variables.

Table 2: Cross Tabulations of How Often Fraternity Members Self-Reported Consuming Alcohol

\begin{tabular}{llllll}
\hline & Fraternity Members & \multicolumn{2}{l}{ Non-Fraternity Members } \\
\hline & $\mathbf{N}$ & Percentage & N & Percentage & \\
Never & 8 & $3.7 \%$ & 200 & $17.3 \%$ & \\
Less Than Once a Month & 14 & $6.5 \%$ & 214 & $18.5 \%$ & \\
Once or a Twice a Month & 39 & $18.0 \%$ & 253 & $21.8 \%$ & \\
Once or Twice a Week & 128 & $59.0 \%$ & 253 & $21.8 \%$ & \\
Daily or Almost Daily & 28 & $12.9 \%$ & 431 & $37.2 \%$ & \\
& & & & & 77.86 \\
Chi Square Test & & & & & 0.238 \\
Cramer's V Test & & & & & 0.000 \\
P-Value & & & & & \\
\hline
\end{tabular}


Table 3 further provides further support for Hypothesis 2. Of the 217 fraternity members, 8 (3.8\%) admitted to never being drunk, whereas 102 (48.8\%) admitted to being drunk once or twice a week. Of the 1,156 non-fraternity members, $130(13.6 \%)$ admitted to never being drunk, whereas $288(30.1 \%)$ admitted to being drunk once or twice a week. This table indicates that the fraternity members are significantly more likely to self-reporting being drunk is statistically significant at the 0.001 level in both, and again Cramer's V results $(0.200)$ indicate a moderate relationship between the variables.

Table 3: Cross Tabulations of How Often Fraternity Members Self-Reported Being Drunk

\begin{tabular}{llllll}
\hline & \multicolumn{2}{l}{ Fraternity Members } & \multicolumn{2}{l}{ Non-Fraternity Members } \\
\hline & $\mathbf{N}$ & Percentage & $\mathbf{N}$ & Percentage \\
Never & 8 & $3.8 \%$ & 130 & $13.6 \%$ & \\
Less Than Once a Month & 40 & $19.1 \%$ & 251 & $26.2 \%$ \\
Once or Twice a Month & 50 & $23.9 \%$ & 277 & $28.9 \%$ & \\
Once or Twice a Week & 102 & $48.8 \%$ & 288 & $30.1 \%$ & \\
Daily or Almost Daily & 9 & $4.3 \%$ & 11 & $1.1 \%$ & \\
& & & & & 46.711 \\
Chi Square Test & & & & & 0.200 \\
Cramer's V Test & & & & & 0.000 \\
P-Value & & & &
\end{tabular}

Table 4 shows the cross-tabulation of fraternity members who self-reported drinking or using drugs prior to the incident, testing Hypothesis $3 a$. Of the 10 fraternity members, they all self- reported drinking alcohol prior to the incident. Of the 23 non-fraternity members, 15 (68.2\%) reported drinking alcohol prior to the incident. This table indicates that fraternity members are more inclined to self- report they themselves drank prior to attempting or committing sexual assault. These results are statistically significant at the 0.05 level, and in accordance to the Cramer's V test (0.357) have a strong association with one another, offering support for Hypothesis $3 a$. 
Table 4: Cross-Tabulation of Fraternity Members Who Self-Reported Drinking Prior to the Incident

\begin{tabular}{lllll}
\hline & \multicolumn{2}{c}{ Fraternity Members } & \multicolumn{2}{l}{ Non-Fraternity Members } \\
\hline & $\mathbf{N}$ & Percentages & $\mathbf{N}$ & \multicolumn{1}{c}{ Percentages } \\
Drinking & 10 & $100 \%$ & 15 & $68.2 \%$ \\
Not Drinking & 0 & 0 & 7 & $31.8 \%$ \\
& & & & 4.037 \\
Chi-Square Test & & & & 0.357 \\
Cramer's V Test $_{\text {P-Value }}^{\text {a }}$ & & & & 0.069 \\
\hline
\end{tabular}

Note: a indicates that Fisher's Exact Test was used

Table 5 shows the cross-tabulation of fraternity members who self-reported being drunk before committing or attempting to commit sexual assault, additionally testing Hypothesis $3 a$. Of the 10 fraternity members, nine (90\%) self-reported being drunk prior to the incident. Of the 16 non-fraternity members, 16, they all self-reported being drunk prior to the incident. As indicated, fraternity members are less inclined to admit to being drunk prior to the incident. These results are not statistically significant, and do not offer any support for Hypothesis $3 a$. However, the Cramer's V test (0.254), does show that they have a moderate association with one another.

Table 5: Cross-Tabulation of Fraternity Members who Self-Reported Being Drunk Prior to the Incident

\begin{tabular}{|c|c|c|c|c|c|}
\hline & \multicolumn{2}{|c|}{ Fraternity Members } & \multicolumn{3}{|c|}{ Non-Fraternity Members } \\
\hline & $\mathbf{N}$ & Percentages & $\mathbf{N}$ & Percentages & \\
\hline Drunk & 9 & $90 \%$ & 16 & $100 \%$ & \\
\hline Not Drunk & 1 & $10 \%$ & 0 & 0 & \\
\hline Chi-Square Test & & & & & 1.664 \\
\hline $\begin{array}{l}\text { Cramer's V Test } \\
\text { P-Value }\end{array}$ & & & & & $\begin{array}{l}0.254 \\
0.385\end{array}$ \\
\hline
\end{tabular}

Note: a indicates that Fisher's Exact Test was used

Lastly, Table 6 illustrates the results of the cross-tabulation of fraternity members who reported the victim was drinking or using drugs prior to the incident, testing Hypothesis $3 b$. Of the 10 fraternity members who admitted to committing or attempting to commit sexual assault, 9 
(90\%) indicated the victim was drinking prior to the incident. Of the 23 non-fraternity members who admitted to committing or attempting to commit sexual assault, 17 (73.9\%) indicated the victim was drinking prior to the incident. These findings are not statistically significant and do not offer any support for Hypothesis 3b. However, the Cramer's V test (0.290) indicates a moderate association between the variables.

Table 6: Cross-Tabulation of Fraternity Members Who Reported the Victim was Drinking or Using Drugs Prior to the Incident

\begin{tabular}{lllll}
\hline & \multicolumn{2}{l}{ Fraternity Members } & \multicolumn{2}{l}{ Non-Fraternity Members } \\
\hline & $\mathbf{N}$ & Percentages & $\mathbf{N}$ & Percentages \\
Drinking & 9 & $90 \%$ & 17 & $73.9 \%$ \\
Using Drugs & 0 & 0 & 1 & $4.3 \%$ \\
Both Drinking and Using Drugs & 1 & $10 \%$ & 1 & $4.3 \%$ \\
Neither & 0 & 0 & 4 & $17.4 \%$ \\
& & & & 2.770 \\
Chi Square Test & & & & 0.290 \\
Cramer's V Test & & & & 0.543 \\
P-Value & & & & \\
\hline
\end{tabular}

Note: a indicates that Fisher's Exact Test was used

\section{DISCUSSION}

On many college campuses, fraternities tend to be at the center of the party culture, hosting parties and providing underage students with alcohol (Krebs et al. 2007; Weiss, 2013). Within this party culture, sexual assault is more likely to occur when the woman is too incapacitated to consent (Krebs et al. 2007; Mohler-Kuo, 2004). Analysis of alcohol consumption and fraternity membership support these findings. In support of DeKeseredy and Schwartz's (1993) male peer support model, the findings from the present study show that there is some connection between fraternity membership and alcohol consumption that contributes to sexual assault. 


\section{Hypothesis 1: Fraternity members are more likely to sexually assault than non-fraternity members.}

The current study shows some statistical evidence that fraternity members sexually assault more than non-fraternity members. The statistical evidence shows that the probability is small that the relationship between fraternity members and sexual assault happened by chance $(\mathrm{p}<0.05)$. In other words there is a higher probability of a fraternity member sexually assaulting than a non-fraternity member. This statistical evidence shows support for Hypothesis 1 and previous research that suggest fraternity members are more likely to commit sexual assault than non-fraternity members (Foubert et al., 2007, Krebs et al., 2007).

In previous literature, Foubert et al. (2007) found that in their first year of college, 8 percent of fraternity members in comparison to the 2.5 percent of non- fraternity members commit sexual assault. Similarly, we found that 2.8 percent of fraternity members in comparison to the 0.9 percent of non-fraternity members attempted to commit sexual assault on an incapacitated victim. Also, 3.7 percent of fraternity members in comparison to the 1.4 percent of non-fraternity members committed sexual assault on an incapacitated victim. These results add to the literature of campus-wide sexual assault, in showing how fraternity members sexually assault more than non-fraternity members.

However, results from the Cramer's V measure results suggest that although statistically significant, there is only a weak correlation ( 0.065 attempted and 0.064 committed) between fraternity membership and sexual assault. Thus there remains to be a lack of practical significance. This lack of practical significance questions the robustness of the results supporting Hypothesis 1 and seems to support the literature suggesting no relationship between fraternity members and sexual assault (Harford et al., 2003). 
Although these findings do offer some support for Hypothesis 1, there are conflicting results about the relationship between fraternity membership and sexual assault. This may be due to the fact that college-aged males have not had proper education on what constitutes sexual assault. They may be encouraged by the college party culture to "score" and see it as an opportunity. They may also feel as if their actions will warrant no harm. Future researchers should utilize both interviews and surveys targeted at college-aged males, either as a general student or fraternity members, in order to assess their definitions of what does and does not constitute assault.

In looking at the full male peer support model (Figure 1), these findings link Membership in Social Groups to Woman Abuse thereby offering some support to the theory. Fraternity men have a reputation for being the "big men on campus." In wanting the esteem that comes with being a fraternity member, men pledge their allegiance to a fraternity and compete with other pledges for this brotherly bond (DeSantis, 2007). Most of these pledging rituals are designed to separate the strong from the weak. Pledges that are less likely to be sexually competitive typically drop out of the pledging process (Bogle, 2008; Martin and Hummer, 1989). This self-selection process may therefore create a pool of fraternity members who are likely to sexually assault. If this is the case, it may be the case that fraternities do not create sexually assaultive males but rather foster initially held abusive beliefs. A potential line of fruitful research for male peer support theorists could include fleshing out the extent to which all-male groups like fraternities either 1) create woman abusers or 2) encourage already existing tendencies toward abuse.

\section{Hypothesis 2: Fraternity members are more likely to consume alcohol than non-fraternity} members. 
The current study provides strong evidence that fraternity members consume alcohol more frequently than non-fraternity members. The statistical evidence shows that the probability is small that the relationship between fraternity membership and alcohol consumption occurs by chance $(\mathrm{p}<0.05)$, meaning that there is a higher probability of a fraternity member regularly consuming alcohol than a non-fraternity member. The results from the Cramer's V measure results further support this strong relationship. I find a moderately strong correlation $(0.238$ consumption of alcohol and 0.200 reports of being drunk) between fraternity membership and alcohol consumption. Taken together these results provide both statistical and practical support for the finding that fraternity members regularly consume more alcohol, thus supporting Hypothesis 2.

In looking at the full male peer support model (Figure 1), these findings support the theoretical relationship between Membership in Social Groups and Heavy Drinking offering some support to the theory. As previous literature indicated, fraternity members regularly consume more alcohol, and binge drink much more frequently than non-fraternity members (Cashin, Presley and Meilman, 1998). Similarly, we found that 59\% of fraternity members consumed alcohol once or twice a week in comparison to the $21.8 \%$ of non-fraternity members. Also, we found that $48.8 \%$ of fraternity members admit to being drunk once or twice a week in comparison to the $30.1 \%$ of non-fraternity members. These results add to the literature of campus-wide substance abuse, showing that fraternity members regularly consume more alcohol and binge drink more frequently than non-fraternity members.

For future research, I suggest the researcher utilizes surveys and interviews aimed at understanding the party culture, and alcohol consumption. These questions should be conversation like, asking questions about with whom, why and how alcohol is consumed. By 
getting a better grasp on the party culture, future researchers can thoroughly explain the connecting between male groups and alcohol. Also, it has been suggested by previous literature, that alcohol consumption is seen as a verification of masculinity (DeSantis, 2007). I also implore that future researchers explore this more. Why is it seen as a verification of masculinity? How is it seen as a verification of masculinity?

\section{Hypothesis 3a: Fraternity members are more likely to consume alcohol prior to sexually assaulting incapacitated women than non-fraternity members.}

The current study shows a lack of statistical evidence to suggest that fraternity members are more likely to consume alcohol prior to sexually assaulting. The lack of statistical evidence does not offer any support for Hypothesis $3 a$. However, results from the Cramer's V measure results suggest that although not statistically significant, there is a strong correlation $(0.357)$ between fraternity membership and drinking prior to sexually assaulting. Table 4 shows that all fraternity members who responded to this question, report they were drinking prior to the incident. In addition there is a moderate correlation (0.254) between fraternity membership and being drunk prior to sexually assaulting. However these results are in the opposite direction:

Table 5 shows that now 100 percent of non-fraternity members were reported being drunk prior to the incident.

In looking at the full male peer support model (Figure 1), these findings do not conclusively link Membership in Social Groups to Heavy Drinking and Woman Abuse. However, one reason for these divergent results may link back to the Narrow Conception of Masculinity advocated by fraternities and other all-male groups. Although heavy drinking is often a part of male culture generally, being drunk may not be seen as particularly masculine. For instance, fraternities may propagate the message that a "real man" never gets drunk - he can 
hold his liquor. IF this message is salient to fraternity members, they may be less likely to admit to researchers they were drunk prior to acts of sexual assault. Thus, the divergence between practical and statistical significance may be due to spuriousness caused by the missing variable. Future research should look to operationalize measures of masculine conceptions in order to test this possibility.

There is very little literature explaining the distinctions between casually drinking and being drunk. There is also very little literature on responsibility and how it links to levels of alcohol consumption and behavior. It would be interesting if future research focused on deciphering the degrees of alcohol consumption and the absolvent of responsibility. I suggest for future research, that researchers utilize interviews and focus groups aimed at explaining the levels of intoxication and the behavior exemptions associated with each.

\section{Hypothesis 3b: Fraternity members are more likely to target and sexually assault incapacitated women than non-fraternity members.}

The current study shows a lack of statistical evidence to suggest that fraternity members are more likely to target incapacitated women than non-fraternity members. The lack of statistical evidence does not offer any support for Hypothesis $3 b$. This lack of statistical evidence may be due to the small sample size $(\mathrm{N}=33)$. However the results from the Cramer's $\mathrm{V}$ measure results suggest a moderate correlation (0.290) between fraternity membership and targeting incapacitated women. Unlike the statistical findings, these results suggest practical significance showing that fraternity members may be more likely to target incapacitated women. These findings indicate that these results are inconclusive and should not be dismissed but examined further. 
One reason for these conflicting findings may be due to similarities in the wordings of the dependent and independent variables. Recall that the dependent variables asked respondents whether they had committed or attempted sexual assault on an incapacitated victim (i.e. unable to provide consent or stop what was happening because they were passed out, drugged, drunk, incapacitated, or asleep). The independent variable measuring victim's drug and alcohol use asked, again from the offender's perspective, if the victim was voluntarily using alcohol and/or drugs. Such similarities regarding victim inebriation may create problems for interpretation of the questions. For instance, we may be measuring victim inebriation twice or offenders are misreporting the context of the assault in one question but not in another. More clearly worded questions may provide a stronger test of this hypothesis.

This hypothesis is not testing an explicit part of the full male peer support theory (Figure 1) but instead acts as an ancillary hypothesis I wanted to test. I do implore future researchers to explore the link between victim intoxication and sexual assault. For this, I suggest utilizing interviews and focus groups for again, these methods are more conversational. Because the current study used self-report questions, many males may lie or choose to not answer questions found to be incriminating. I would also advise that future researcher ask questions about where women are met prior to any drunken sexual conduct. As most rapes occur in homes, is there a difference in meeting women at a fraternity party or at a bar? I would also suggest that future researchers include questions about the party culture.

In general, this research adds to the literature of DeKeseredy and Schwartz's revised model of male peer support on fraternities. By looking at fraternities in the United States, we were able to get a better understanding of how fraternities and alcohol consumption lead to sexual assault. Although all of the survey questions used in the present research are offender- 
based questions and are based on self-reported behavior, there is some evidence to suggest that alcohol does assist in the attempting and completion of sexual assault. Although there were a small number of offenders that came forth, we do get a better understanding of the overall effect of alcohol on sexual assaults.

Previous tests of the modified male peer support theory show that attachments to certain male peer groups and the resources they provide are powerful determinants of campus sexual assault (DeKeseredy and Schwartz, 2013). Note, too, that Frankline, Bouffard, and Pratt (2012) tested the entire model presented in Figure 1 and centered their work on fraternity membership as an example of elite all-male peer groups. They surveyed 255 males at a large northwestern public university. Approximately, 28 percent of the male respondents identified as being fraternity members. They found that the modified male peer support model explained much of the incidence and motivation for sexual assault on the college campus. They found that fraternity members experience greater levels of peer pressure to have sex. Unlike my findings, these researchers found that fraternity membership directly correlates with alcohol consumption leading to sexual assault. The difference in results may be due largely to the large number of fraternity responses. Future research should attempt to do more tests of the entire model presented in Figure 1.

\section{Limitations}

Although these findings offer some support to most of the hypotheses, it should be noted that this research is not without limitations. One drawback of using secondary data is the researchers are hindered by someone else's word choices as evidence in the dependent measure of sexual assault, which focused specifically on incapacitated victimization. Additionally, the inability to survey the desired sample creates a limitation. The original survey was aimed 
primarily at sexual assault victimization on campus and it did contain several questions directed at offenders. Several of the questions asked could have been elaborated on or worded differently. Mostly, these questions should have been asked in a more direct, colloquial manner. Another limitation of this research is the number of fraternity members in comparison to the number of non-fraternity members was disproportionately represented (217 fraternity members and 1,373 non-fraternity members). With these limitations there was a very small sample of self-reports of sexual assaults, both completed and attempted for this research (fraternity members: 6 attempted and 8 committed; non-fraternity members 10 attempted and 16 committed). Due to these limitations, it is suggested that future research employ different methods of obtaining offender based data such as surveys, interviews and ethnographies, similarly to Sanday (2007), directed at better understanding offenders. By focusing on offenders, future research can explore in depth the many ways in which fraternity members fit within the parameters of the modified male peer support model in explaining why they sexually assault. By better understanding the why, the who, the when, the where, and the how of fraternity sexual assault, universities can enact the appropriate rape prevention programs on campus in protecting students.

\section{Policy Implications}

The findings from this research suggest that while the consumption of alcohol does not cause acts of sexual assault, it does aid in the attempts and completions of it. In recent years, many universities have been implementing rape prevention programs directed at men in all-male groups, e.g. fraternities. These programs are targeted at smaller groups of men from different all-male organizations, and are taught by men to explain how not to commit sexual assault. These programs are created with the organizational culture in mind and they do not blame the 
members but counsel change through the explanation of everything that encompasses sexual assault. I urge universities to apply similar programs. Programs like these have proven to help decrease the number of sexual assaults committed on campus, by taking the focus off the victims and applying them to the potential offenders. These programs have been found to make men less likely to believe that "she asked for it" and more empathetic towards rape survivors (Foubert and Newberry, 2006; Foubert et al., 2007; Foubert et al., 2010). Instead of teaching women how to not get raped, these programs are teaching men to not rape. They are also teaching these men how to intervene if they see a potential sexual assault occurring.

An additional response to prevent campus sexual assault and rape has been to implement alcohol bans on campus. Many universities have a "dry campus" where any dormitory, university owned housing, or any location on campus remains to be alcohol free. Taylor et al. (2006) found that alcohol consumption and alcohol related problems are found on "dry campuses" similar to the national trends. These students are still drinking, just not on-campus.

In 2014, President Obama and Vice President Biden instituted the White House Task Force to Protect Students from Sexual Assault. Soon after this establishment of this task force, they launched the "It's On Us" campaign. Many universities have jumped on board and are enacting the campaign's plans:

1. To recognize that non-consensual sex is sexual assault.

2. To identify situations in which sexual assault may occur.

3. To intervene in situations where consent has not or cannot be given.

4. To create an environment in which sexual assault is unacceptable and survivors are supported (The White House, 2014).

This campaign aims to shift the responsibility from the victim and put it on everybody. By showing that any action big or small to combat sexual assault, can help prevent it. Awareness 
efforts are being made through endorsements by the NCAA, social media outlets, and several celebrities. This campaign is taking strides in creating safe environments for all.

\section{CONCLUSION}

My research added to the missing literature for DeKeseredy and Schwartz's revised model of male peer support on fraternities. Consistent with previous literature, this research found an association with fraternity membership and alcohol consumption leading to attempted or committed sexual assault. With many incoming freshman weighing their decisions of what school to attend based on the reputations of the party scene, fraternities are often found at the central hub of the party culture. Fraternities provide a place for students to party, they supply underage students alcohol, and they are a place where inhibitions are lost. This does, however, come with a price: it puts these students, mainly women, in harm's way. It allows them to fall victim to sexual assault at the cost of drinking one too many. In understanding how fraternities and their alcohol consumption affects the likelihood of sexual assault, we can understand and learn how to protect these women. 


\section{REFERENCES}

Abbey, A. (2002). Alcohol-Related Sexual Assault: A Common Problem among College Students. Journal of Studies on Alcohol, 14, 118-128.

Abbey, A., Ross, L., McDuffie, D., \& McAuslan, P. (1996). Alcohol And Dating Risk Factors For Sexual Assault Among College Women. Psychology of Women Quarterly, 20, 147169.

Abbey, A., Mcauslan, P., \& Ross, L. (1998). Sexual Assault Perpetration by College Men: The Role of Alcohol, Misperception of Sexual Intent, and Sexual Beliefs and Experiences. Journal of Social and Clinical Psychology, 17, 167-195.

Armstrong, E., \& Hamilton, L. (2013). Paying for the party: How College Maintains Inequality. Harvard University Press.

Armstrong, E., Hamilton, L., \& Sweeney, B. (2006). Sexual Assault On Campus: A Multilevel, Integrative Approach To Party Rape. Social Problems, 53(4), 483-499.

Beck, V., Boys, S., Rose, C., \& Beck, E. (2012). Violence Against Women in Video Games: A Prequel or Sequel to Rape Myth Acceptance? Journal of Interpersonal Violence, 27(15), 3016-3031.

Beyerstein, L. (2011). "No Means Yes, Yes Means Anal" Frat Banned From Yale | Big Think. Retrieved May 5, 2015, from http://bigthink.com/focal-point/no-means-yes-yes-meansanal-frat-banned-from-yale

Bleecker, E., \& Murnen, S. (2005). Fraternity Membership, the Display of Degrading Sexual Images of Women, And Rape Myth Acceptance. Sex Roles, 53, 487-493. 
Boeringer, S. (1999). Associations Of Rape-Supportive Attitudes With Fraternity And Athletic Participation. Violence Against Women, 5(1), 81-90.

Boeringer, S., Shehan, C., \& Akers, R. (1991). Social Contexts and Social Learning in Sexual Coercion and Aggression: Assessing the Contribution of Fraternity Membership. Violence Against Women, 5, 81-90.

Bogle, K. (2008). Hooking up: Sex, Dating, and Relationships on Campus. New York: New York University Press.

Bridges, A., Wosnitzer, R., Scharrer, E., Sun, C., \& Liberman, R. (2010). Aggression and Sexual Behavior in Best-Selling Pornography Videos: A Content Analysis Update. Violence Against Women, 16, 1065-1085.

Buzzell, T. (2005). The Effects Of Sophistication, Access And Monitoring On Use Of Pornography In Three Technological Contexts. Deviant Behavior, 26, 109-132.

Brown, S., Goldman, M., Inn, A., \& Anderson, L. (1980). Expectations Of Reinforcement From Alcohol: Their Domain And Relation To Drinking Patterns. Journal of Consulting and Clinical Psychology, 48, 419-426.

Clapp, J., Ketchie, J., Reed, M., Shillington, A., Lange, J., \& Holmes, M. (2008). Three Exploratory Studies of College Theme Parties. Drug \& Alcohol Review, 27(5), 509-518.

Caron, S., Moskey, E., Hovey, C. (2004). Alcohol Use Among Fraternity and Sorority Members Looking at Change Over Time. Journal of Alcohol \& Drug Education. 47(3), 51-66.

Carroll, J., Padilla-Walker, L., Nelson, L., Olson, C., McNamara Barry, C., \& Madsen, S. (2008). Generation XXX: Pornography Acceptance And Use Among Emerging Adults. Journal of Adolescent Research, 23, 6-30. 
Connell, R. (1987). Gender And Power: Society, The Person, And Sexual Politics. Stanford, Calif.: Stanford University Press.

Connell, R.W. (1995). Masculinities. Berkeley, CA: University of California Press.

Copenhaver, S., \& Grauerholz, E. (1991). Sexual Victimization Among Sorority Women: Exploring The Link Between Sexual Violence And Institutional Practices. Sex Roles, 24, $31-41$.

DeJesus, I. (2015). Penn State fraternity scandal: Police urge witnesses, victims to come forward. Retrieved July 7, 2015, from http://www.pennlive.com/midstate/index.ssf/2015/03/kappa_delta_rho_penn_state_fra.ht $\mathrm{ml}$

DeKeseredy, W. (2008). Theory of Male Peer Support. In Encyclopedia of Interpersonal Violence (p. 424). Thousand Oaks, CA: Sage.

DeKeseredy, W., \& Schwartz, M. (1993). Male Peer Support And Woman Abuse: An Expansion Of Dekeseredy's Model. Sociological Spectrum, 393-413.

DeKeseredy W., \& Schwartz, M. (1998) Male Peer Support And Woman Abuse In Postsecondary School Courtship: Suggestions For New Directions In Sociological Research. In R.K. Bergen (Ed.). Issues in Intimate Violence (pp. 83-96). Thousand Oaks, CA: Sage.

DeKeseredy, W., \& Schwartz, M. (2013). Male Peer Support and Violence Against Women the History and Verification of a Theory. Boston, MA: Northeastern University Press.

DeSantis, A. (2007). Inside Greek U Fraternities, Sororities, and The Pursuit Of Pleasure, Power, and Prestige. Lexington: University Press of Kentucky. 
DeSimone, J. (2007). Fraternity Membership and Binge Drinking. Journal of Health Economics 26(5) 950-967.

Dean, J. (2013). Heterosexual Masculinities, Anti-Homophobias, and Shifts in Hegemonic Masculinity: The Identity Practices of Black and White Heterosexual Men. The Sociological Quarterly, 54, 534-560.

Dietz, T. L. (1998). An Examination Of Violence And Gender Role Portrayals In Video Games: Implications For Gender Socialization And Aggressive Behavior. Sex Roles, 38(5/6), $425-442$.

Donaldson, M. (1993). What Is Hegemonic Masculinity? Theory and Society, 22(5), 643-657.

Eagly, A. (1978). Sex Differences In Influenceability. Psychological Bulletin, 86-116.

Foubert, J., Newberry, J., \& Tatum, J. (2007). Behavior Differences Seven Months Later: Effects Of A Rape Prevention Program. Journal of Student Affairs Research and Practice, 44(4).

Foubert, J., Brosi, M., \& Bannon, R. (2011). Pornography Viewing among Fraternity Men: Effects on Bystander Intervention, Rape Myth Acceptance and Behavioral Intent to Commit Sexual Assault. Sexual Addiction \& Compulsivity, 18, 212-231.

Foubert, J. D. \& Newberry, J. T. (2006). Effects Of Two Versions Of An Empathy-Based Rape Prevention Program On Fraternity Men's Rape Survivor Empathy, Rape Myth Acceptance, Likelihood Of Raping, And Likelihood Of Committing Sexual Assault. Journal of College Student Development, 47, 133-148.

Foubert, J. D., Godin, E., \& Tatum, J. (2010). In Their Own Words: Sophomore College Men Describe Attitude And Behavior Changes Resulting From A Rape Prevention Program Two Years After Their Participation. Journal of Interpersonal Violence, 25, 2237-2257. 
Franklin, C., Bouffard, L., \& Pratt, T. (2012). Sexual Assault on the College Campus: Fraternity Affiliation, Male Peer Support, and Low Self-Control. Criminal Justice and Behavior, $39(11), 1457-1480$.

George, W., \& Norris, J. (1991). Alcohol, Disinhibition, Sexual Arousal, And Deviant Sexual Behavior. Alcohol Health \& Research World, 15, 133-138.

General History of Fraternities and Sororities in the United States. (2014). Retrieved May 5, 2015, from http://www.sjsu.edu/getinvolved/frso/history/usfslhistory/

Harford, T., Wechsler, H., \& Muthén, B. (2003). Alcohol-Related Aggression And Drinking At Off-Campus Parties And Bars: A National Study Of Current Drinkers In College. Journal of Studies on Alcohol J. Stud. Alcohol, 64(5), 704-711.

Harrington, N., \& Leitenberg, H. (1994). Relationship Between Alcohol Consumption and Victim Behaviors Immediately Preceding Sexual Aggression By An Acquaintance. Violence and Victims, 9, 315-324.

Herzog, K. (2015). UWM Revokes Frat's Charter Over Drunken Party. Retrieved May 5, 2015, from http://www.jsonline.com/news/education/uw-milwaukee-revokes-fraternityscharter-over-drunken-party-b99401727z1-284633091.html

Kilpatrick, D., Resnick, H., Ruggiero, K., Conoscenti, L., \& McCauley, J. (2007). DrugFacilitated, Incapacitated, and Forcible Rape: A National Study. Medical University of South Carolina.

Kimmel, M. (2005). The Gender of Desire Essays on Male Sexuality. Albany, NY: State University of New York Press.

Kimmel, M. (2008). Guyland: The Perilous World Where Boys Become Men. New York: Harper. Kingkade, T. (2013). Georgia Tech Frat Email About 'Luring Your Rapebait' Condemned By 
Everyone. Retrieved May 5, 2015, from

http://www.huffingtonpost.com/2013/10/08/georgia-tech-frat-emailrapebait_n_4063101.html

Kingkade, T. (2014). Texas Tech Investigating Frat For 'No Means Yes, Yes Means Anal' Sign (. Retrieved May 5, 2015, from http://www.huffingtonpost.com/2014/09/23/texas-tech-nomeans-yes-fraternity-phi-delt_n_5865606.html

Koss, M., Gidycz, C., \& Wisniewski, N. (1987). The Scope Of Rape: Incidence And Prevalence Of Sexual Aggression And Victimization In A National Sample Of Higher Education Students. Journal of Consulting and Clinical Psychology, 162-170.

Krebs, C., Lindquist, C., Warner, T., Fisher, B., Martin, S. (2007) Prevalence, Context, and Reporting of Drug-Facilitated Sexual Assault on Campus of Two Large Public Universities in the United States, 2005-2006 [Data file]. Retrieved from http://doi.org/10.3886/ICPSR22060.v1

Krebs, C., Lindquist, C., Warner, T., Fisher, B., \& Martin, S. (2007). The Campus Sexual Assault (CSA) Study. National Institute of Justice.

Krebs, C.P., Linquist C.H., Warner, T.D., Fisher, B.S., Martin, S.L. (2009). College Women's Experiences With Physically Forced, Alcohol- or Other Drug-Enabled, and DrugFacilitated Sexual Assault Before and Since Entering College. Journal of American College Health; 57(6): 639-647.

Levant, R. (1994). Male Violence Against Female Partners: Roots in Male Socialization and Development. In Stress and Emotion: Anxiety, Anger and Curiosity (Vol. 15). Washington DC: Taylor \& Francis.

Loh, C., Gidycz, C., Lobo, T., \& Luthra, R. (2005). A Prospective Analysis of Sexual Assault 
Perpetration: Risk Factors Related to Perpetrator Characteristics. Journal of Interpersonal Violence, 20, 1325-1348.

Martin, P., \& Hummer, R. (1989). Fraternities And Rape On Campus. Gender \& Society, 3(4), 457-473.

Menning, C. (2009). Unsafe At Any House?: Attendees' Perceptions Of Microlevel Environmental Traits And Personal Safety At Fraternity And Nonfraternity Parties. Journal of Interpersonal Violence, 24(10), 1714-1734.

Miller, J., Schwartz, M.D. (1992, November). Lewd Lighters and Dick-ee Darts: The Commodification of Women Through Sexual Objects. Paper presented at the annual meetings of the American Society of Criminology, New Orleans.

Mohler-Kuo, M., Downdall, G., Koss, M., \& Wechsler, H. (2004). Correlates of Rape while Intoxicated in a National Sample of College Women. Journal of Studies on Alcohol, 3745.

Moos, R. (1979). Evaluating Educational Environments. San Francisco, CA.: Jossey-Bass.

Murnen, S., \& Kohlman, M. (2007). Athletic Participation, Fraternity Membership, And Sexual Aggression Among College Men: A Meta-analytic Review. Sex Roles, 57, 145-157.

Papadaki, L. (2010). What is Objectification?. Journal of Moral Philosophy, 7(1), 16-36.

Pascoe, C. (2007). Dude, You're a Fag: Masculinity and Sexuality in High School. Berkeley, CA: University of California Press.

Presley, C., Meilman, P., Cashin, J., \& Leichliter, J. (1997). Alcohol And Drugs On American College Campuses: Issues Of Violence And Harassment: A Report To College Presidents. Carbondale, Il: Core Institute, Southern Illinois University. 
Sanday, P. R. (2007). Fraternity Gang Rape: Sex, Brotherhood, and Privilege on Campus. New York: New York University Press.

Schur, E. (1988). The Americanization of Sex. Philadelphia: Temple University Press.

Schwartz, M., \& DeKeseredy, W. (1997). Sexual Assault On The College Campus: The Role Of Male Peer Support. Thousand Oaks, Calif.: Sage Publications.

Schwartz, M., \& Leggett, M. (1999). Bad Dates or Emotional Trauma?: The Aftermath of Campus Sexual Assault. Violence Against Women, 5(3), 251-271.

Simmel, G., \& Wolff, K. (1950). The Sociology of Georg Simmel. Glencoe, Illinois: The Free Press.

Syrett, N. (2009). The Company he Keeps a History of White College Fraternities. Chapel Hill: University of North Carolina Press.

Taylor, D., Johnson, M., Voas, R., \& Turrisi, R. (2006). Demographic and Academic Trends in Drinking Patterns and Alcohol-Related Problems on Dry College Campuses. Journal of Alcohol and Drug Education, 50(4), 35-55.

Testa, M., Livingston, J., Vanzile-Tamsen, C., \& Frone, M. (2003). The Role of Women's Substance Use in Vulnerability to Forcible and Incapacitated Rape. Journal of Studies on Alcohol, 64(6), 756-764.

The White House. (2014, September 19). FACT SHEET: Launch of the "It's On Us" Public Awareness Campaign to Help Prevent Campus Sexual Assault. Retrieved May 23, 2015, from https://www.whitehouse.gov/the-press-office/2014/09/19/fact-sheet-launch-it-s-uspublic-awareness-campaign-help-prevent-campus-

Wechler, H. (1995). Binge Drinking on American College Campuses: A New Look at an Old Problem. Boston, MA: Harvard School of Public Health 
Weiss, K. (2013). Party School Crime, Campus, and Community. Boston: Northeastern University Press. 